\title{
A PILÓTANÉLKÜLI LÉGIJÁRMŰ RENDSZEREK ALKALMAZÁSÁNAK DOKTRINÁLIS MEGKÖZELÍTÉSE A NATO-BAN
}

\author{
DOCTRINAL APPROACHES OF UNMANNED AIRCRAFT SYSTEMS OF THE \\ NATO
}

\author{
KRAJNC Zoltán \\ (ORCID: 0000-0002-5873-3552) \\ krajnc.zoltan@uni-nke.hu
}

\begin{abstract}
Absztrakt
A pilótanélküli légijármüvek katonai alkalmazása már több évtizedes múltra tekint vissza, a Szövetségben a felhasználásuk jelentősége a 90-es években növekedett meg igazán. A tanulmány összegzi a pilótanélküli légijárművek alkalmazásnak doktrinális hátterét, stratégiai koncepcióját. A pilóta nélküli légijármü rendszerek, ugyanolyan platformnak, tekinthetőek, mint a pilóta által vezetett fegyverrendszerek a müveleti alkalmazási formákat illetően. Az UAS-ok gyakorlatilag, mint az adott szerepkörre létrehozott komplex légi támadó kötelékek alkotó elemeiként a képességeiknek megfelelö feladattal integrálódhatnak. A pilóta nélküli légijármü rendszerek széleskörüen alkalmazhatóak a védelmi-, és támadó légi szembenállás, légi csapásmérés eszközeként, valamint felderítömegfigyelö feladatkörökben egyaránt.
\end{abstract}

Kulcsszavak: pilótanélküli légijármü rendszerek, drónok müveleti alkalmazása, NATO müveletek, szabványositás, interoperabilitás

\begin{abstract}
The military use of unmanned aerial vehicles (drones) has some decade-long history. The importance of their use in the Alliance in the 1990s has increased. This study summarizes the doctrinal background and strategic concept of the employment of unmanned aerial vehicles.

Unmanned Aircraft Systems can be considered the almost same platform as pilotdriven weapon systems for operational applications.

UAS's can effectively integrate as a constituent element of Composite Air Operations created for a given role with a task appropriate to their abilities.

Unmanned Aircraft Systems can be widely used as Defensive and Offensive Counter Air, as well as in Reconnaissance and Surveillance missions.
\end{abstract}

Keywords: operational employment of Unmanned Air Systems and drones, NATÓ operations, standardization, interoperability 


\section{BEVEZETÉS 1}

A pilótanélküli légijármüvek katonai alkalmazása már több évtizedes múltra tekint vissza, nem témája a cikknek a történeti áttekintés, az eziránt érdeklődők nagyon részletes ismertetést találhatnak a rendszerek, eszközök evolúciójáról például Szabolcsi R. [1] könyvében. Köztudott, hogy a Szövetségben a felhasználásuk jelentősége a 90 -es években növekedett meg igazán, amikor az amerikai haderőben az MQ-1 Predatorokat és az RQ-4 Global Hawkokat integrálták a légi hadjárataikba.

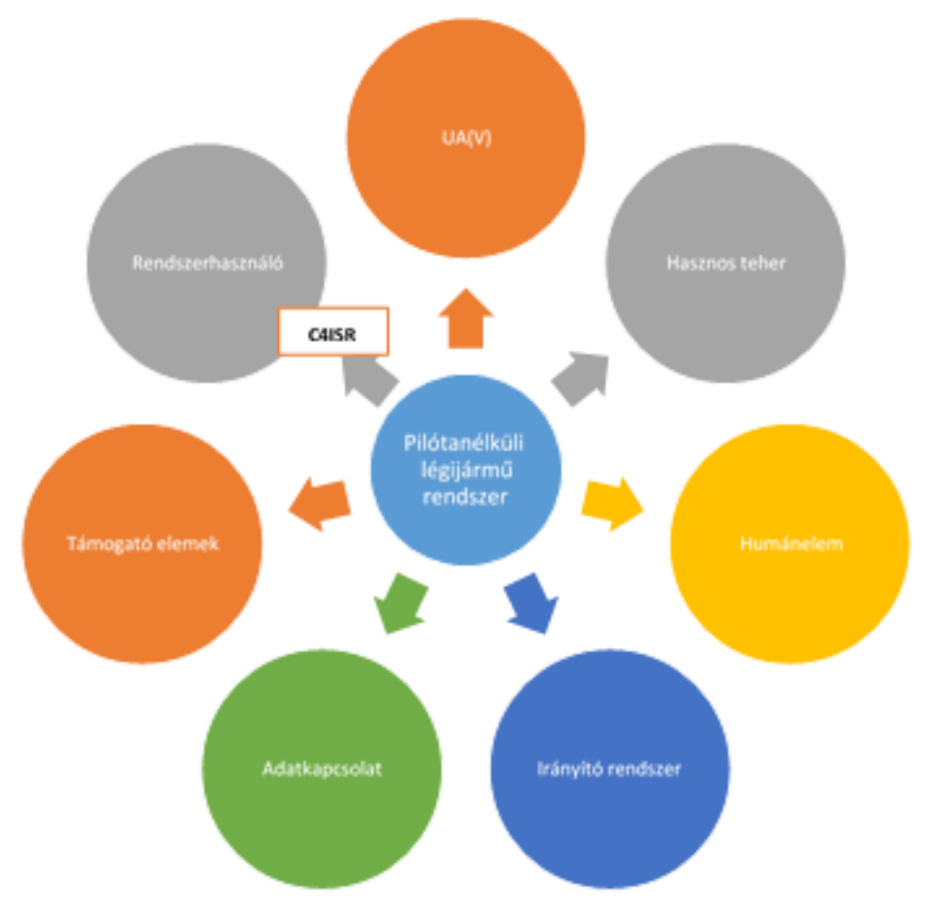

1. sz. ábra: A Pilótanélküli Légijármü Rendszer struktúrája (forrás: Strategic Concept of Employment for Unmanned Aircraft Systems in NATO, 2010)

A tanulmány nem kíván foglalkozni a téma kiterjedt terminológiai és kategorizálási kérdései, az eszközök osztályozása (kategóriákba sorolása) és megnevezése (UAV, UAS, UCAS, UCAV, RPA/RPV, RPAS, stb. $)^{2}$ kérdéseivel, a definíciók mögött lévő fogalmak magyarázata, differenciálása több tudományos és szolgálati közleményben is részletesen megtalálható. [2], [3], [4]

\footnotetext{
1 „A mủ a KÖFOP-2.1.2-VEKOP-15-2016-00001 azonosítószámú, „, A jó kormányzást megalapozó közszolgálatfejlesztés" elnevezésü kiemelt projekt keretében müködtetett Bay Zoltán Ludovika Kiemelt Kutatómühely keretében, a Nemzeti Közszolgálati Egyetem felkérésére készült."

",The work was created in commission of the National University of Public Service under the priority project KÖFOP-2.1.2-VEKOP-15-2016-00001 titled „Public Service Development Establishing Good Governance” in the Zoltan Bay Ludovika Workshop Program."

${ }^{2}$ UAV - Unmanned Aircraft/Vehicle (Drone);

UAS - Unmanned Aircraft System;

UCAV - Unmanned Combat Aircraft System;

UCAS - Unmanned Combat Aircraft System;

RPA/RPV - Remotely Piloted Aircraft

RPAS - Remotely Piloted Aircraft System.
} 
Ebben a cikkben alapvetően a katonai terminológiában releváns pilóta nélküli légijármürendszerek (UAS) kategóriát és rövidítést alkalmazom, amennyiben egyéb aspektusok megkívánják az ettől való eltérést, akkor azt külön jelzem.

Pilótanélküli légijárművek osztályozása

\begin{tabular}{|c|c|c|c|c|c|c|}
\hline Osztály & Kategória & $\begin{array}{l}\text { Alkalmazási } \\
\text { cél (szint) }\end{array}$ & $\begin{array}{l}\text { Alkalmazási } \\
\text { magasság }\end{array}$ & $\begin{array}{l}\text { Normál } \\
\text { hatósugár }\end{array}$ & $\begin{array}{l}\text { Támogatott } \\
\text { parancsnok }\end{array}$ & $\begin{array}{l}\text { Jellemző } \\
\text { platform }\end{array}$ \\
\hline \multirow{3}{*}{$\begin{array}{l}\text { I. osztály } \\
\leq 150 \mathrm{~kg}\end{array}$} & $\begin{array}{l}\text { kisméretü } \\
\geq 20 \mathrm{~kg}\end{array}$ & $\begin{array}{l}\text { harcászati } \\
\text { egység }\end{array}$ & $\begin{array}{l}\text { földfelszín } \\
\text { felett } 5000 \\
\text { lábig }(1,5 \mathrm{~km})\end{array}$ & $50 \mathrm{~km}$ & $\begin{array}{l}\text { ezred, } \\
\text { zászlóalj, } \\
\text { dandár }\end{array}$ & $\begin{array}{l}\text { Luna, Hermes } \\
90\end{array}$ \\
\hline & $\begin{array}{l}\operatorname{mini} \\
2-20 \mathrm{~kg}\end{array}$ & kis alegység & $\begin{array}{l}\text { földfelszín } \\
\text { felett } 3000 \\
\text { lábig }(0,9 \mathrm{~km})\end{array}$ & $25 \mathrm{~km}$ & század & $\begin{array}{l}\text { Scan Eagle, } \\
\text { Skylark, } \\
\text { Raven, Aladin, } \\
\text { DH3, Strix }\end{array}$ \\
\hline & $\begin{array}{l}\text { mikró } \\
\leq 2 \mathrm{~kg}\end{array}$ & kis alegység & $\begin{array}{l}\text { földfelszín } \\
\text { felett } 200 \text { lábig } \\
(60 \mathrm{~m})\end{array}$ & $5 \mathrm{~km}$ & $\begin{array}{l}\text { szakasz, raj, } \\
\text { kezelőszemély } \\
\text { zet }\end{array}$ & Black Widow \\
\hline $\begin{array}{l}\text { II.osztály } \\
150 \text { kg - } \\
600 \text { kg }\end{array}$ & harcászati & $\begin{array}{l}\text { harcászati } \\
\text { információk }\end{array}$ & $\begin{array}{l}\text { földfelszín } \\
\text { felett } 10.000 \\
\text { lábig (3 km) }\end{array}$ & $200 \mathrm{~km}$ & dandár & $\begin{array}{l}\text { Sperwer, Iview } \\
250 \text {, Hermes } \\
\text { 450, Aerostar, } \\
\text { Ranger }\end{array}$ \\
\hline \multirow{3}{*}{$\begin{array}{l}\text { III. osztály } \\
\geq 600 \mathrm{~kg}\end{array}$} & csapásmérés & & $\begin{array}{l}\text { földfelszín } \\
\text { felett } 65.000 \\
\text { lábig }(20 \mathrm{~km})\end{array}$ & nem limitált & hadszíntéri & \\
\hline & $\begin{array}{l}\text { HALE - } \\
\text { nagymagassá } \\
\text { gú eszközök }\end{array}$ & & $\begin{array}{l}\text { földfelszín } \\
\text { felett } 65.000 \\
\text { lábig }(20 \mathrm{~km})\end{array}$ & nem limitált & hadszíntéri & Global Hawk \\
\hline & $\begin{array}{l}\text { MALE - } \\
\text { közepes } \\
\text { magasságú } \\
\text { eszközök }\end{array}$ & & $\begin{array}{l}\text { földfelszín } \\
\text { felett } 45.000 \\
\text { lábig }(14 \mathrm{~km})\end{array}$ & nem limitált & összhaderőnemi & $\begin{array}{l}\text { Predator A, B, } \\
\text { Heron, Heron } \\
\text { TP, Hermes } \\
900\end{array}$ \\
\hline
\end{tabular}

1. táblázat NATO UAS osztályozási ajánlás (forrás: Strategic Concept of Employment for Unmanned Aircraft Systems in NATO; January 2010, NATO, Joint Air Power Competence Centre, 6. oldal)

A pilóta nélküli légijármü-rendszerekre, ,nomen est omen” rendszerként kell tekintenünk, melyek a légijármü mellett, a küldetéshez szükséges összes elemet (eszközök, hálózatok, személyzet, hasznos teher, az 1. sz. ábra szerint) is magukban foglalják. A pilóta nélküli légijármü-rendszerek kritikus jelentőségüek összhaderőnemi és koalíciós szinten is. Az egyre növekvő alkalmazási igény miatt egyre fontosabb a bevetési és rendszerintegrációs kihívások kezelése. A pilóta nélküli és a pilóták vezette eszközök alkalmazását zökkenőmentesen kell összehangolni a haderőnemek között, a pilóta nélküli légijármü-rendszerekkel beszerezhető jelenlegi és jövőbeli C4ISR-adatokat (vezetés, irányítás, kommunikáció és számítástechnika, hírszerzés, megfigyelés és felderítés) be kell illeszteni az információfeldolgozási ciklusba. 


\section{NATO ÖSSZHADERŐNEMI LÉGIERŐ TUDÁSKÖZPONT STRATÉGIAI KONCEPCIÓJA}

A NATO Összhaderőnemi Légierő Tudásközpont (Joint Air Power Competence Centre, Kalkar, Németország) küldetése, hogy a Szövetség döntéshozóit támogassa a légierőt, a légi hadviselést illető transzformációs, fejlesztési kérdésekben. A NATO Szövetséges Transzformációs Parancsnokság (NATO - Allied Command Transformation, Norfolk, Egyesült Államok) keretében müködő többnemzeti szervezet természetesen az egyre nagyobb jelentőséggel bíró pilótanélküli légijármü rendszerek alkalmazásának, fejlesztésének főkérdéseivel is foglalkozik, folyamatosan kutatja a témát, publikálja a kutatási eredményeket és integrálja azokat a Szövetség doktrinális rendszerébe.

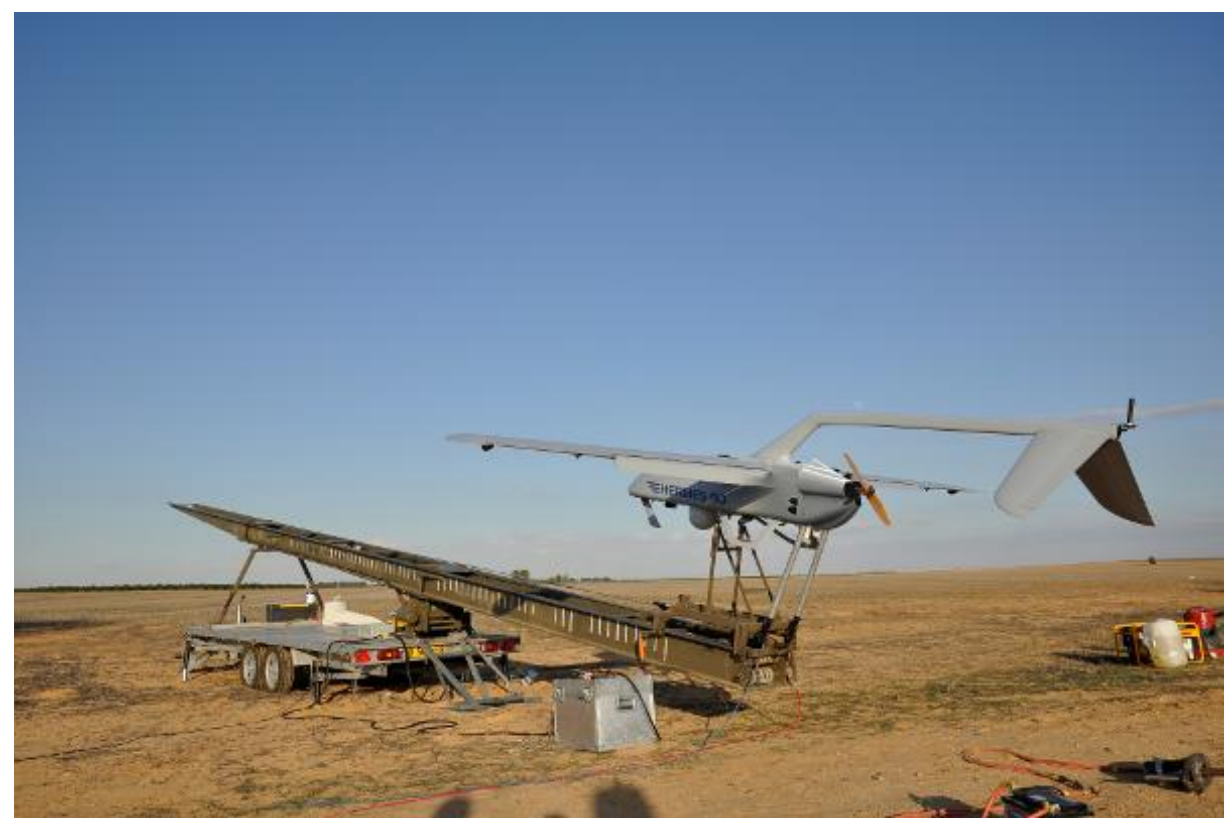

1. kép: Hermes 90 pilótanélküli légijármü rendszer (forrás: https://www.airforce-technology.com/projects/hermes-90tactical-unmanned-aircraft-system-uas/)

A szervezet 2010-ben kiadott pilóta nélküli légijármü-rendszerek alkalmazásának stratégiai koncepciója (Strategic Concept of Employment for Unmanned Aircraft Systems in NATO; January 2010, NATO, Joint Air Power Competence Centre, von-Seydlitz Kaserne, Kalkar, Germany) komplex módon összegezi az UAS-ok müveleti bevetéseinek alapelveit és releváns eljárásait. [5]

A dokumentumban bemutatásra kerül a mai és a jövőbeli pilóta nélküli légijármü rendszerek képességeinek alkalmazása az összhaderőnemi erők műveleti tervezői számára, kifejezetten az összhaderőnemi müveleti forgatókönyvek esetére. Ehhez a NATO stratégiai összefüggéseit és jövőbeli környezetét a „,Sokrétü Jövő Projekt” (Multiple Future Project - MFP) és a „,Védelmi Követelmények Attekintése” (Defence Requirements Review - DRR) projektekből vették.

A pilóta nélküli légijármü rendszerek alkalmazási elveinek jövőbeli következményei több területet is érintenek, bevetésüket a katonai müveletek teljes keresztmetszetébe integrálni szükséges. A pilóta nélküli légijármü rendszerekre tekintettel kell lenni az egységesítési egyezmények (STANAG-ek), a doktrínák, a harcászat technikai eljárások kialakításakor és módosításakor is. Be kell őket illeszteni a NATO oktatási, kiképzési, gyakorlati és kiértékelési rendszereibe egyaránt. Ezek az elvek segítik a technológiai fejlesztéseket, a beszerzésekhez szükséges hadmüveleti követelmények kialakítását és támogatják a parancsnokokat a pilóta nélküli légijármü rendszerek képességeinek integrált és hatékony kihasználásában. 
A pilóta nélküli légijármü rendszerek és a pilóták vezette légi jármüvek sok tekintetben hasonlítanak egymásra: repülnek, fegyelmezett, profi üzemeltetőik vannak, hasonló légi kiszolgáló és logisztikai támogató személyzetük van. Azonban alapvető különbségként említhetjük, hogy a pilóta nélküli gépek emberi élet (pilóta) veszélyeztetése nélkül képesek müködni a veszélyes környezetekben. Ugyanekkor ez azt is jelenti, hogy a pilóták hiánya szükségessé teszi az irányításhoz és ellenőrzéshez fejlett, és megbízható adatkapcsolatok meglétét. A pilóta nélküli légijármü rendszerek használatával a parancsnokok minimalizálhatják a bevetési kockázatot a személyzet és a haditechnikai eszközök számára, és mivel emberélet nincs közvetlen veszélyben, fokozódhat a parancsnok hajlandósága is az eszközök kockázatosabb bevetésére. A bevetések megítélésének politikai kockázata is csökken. A pilóta nélküli légi jármü vegyi, biológiai, radiológiai és nukleáris érzékelőket is vihet magával olyan területekre, melyek a pilóták vezette gépek személyzetére komoly kockázatokkal járna. A pilóta nélküli gépek olyan körülmények között is bevethetőek (pl. kedvezőtlen időjárás, műszaki problémák, kevés üzemanyag), ahol pilóta vezette gépeket a parancsnokok már nem biztos, hogy kockáztatnának. A repülőgép vezetői kabin szükségtelen volta miatt a pilóta nélküli légijármü rendszereket igény szerint bármilyen méretben elkészíthetővé tette, ezáltal a méretei és vele a hatásos radarkeresztmetszete is kisebb lehet,

A pilóta nélküli légijármü rendszerek feladatai a pilóták vezette gépekénél sokkal könnyebben megváltoztathatóak a bevetés közben is. A pilóta nélküli gépek küldetéstől és felszereléstől függően sokszor hamarabb indíthatóak és tovább maradhatnak a levegőben, mint pilóta vezette vetélytársaik. A távollévő ember persze kihívást is jelent a légtér integrációban, többek között a nem szegregált légtérben való alkalmazás esetén. A kezelö látótere, helyzetfelismerése is korlátozottabb, így erre az a megoldás mutatkozik leginkább, hogy a pilóta nélküli és a pilóta vezette eszközök szegregált légtérben kerüljenek alkalmazásra. Azonban kijelenthetjük, hogy hosszabb idő perspektívában a végső cél a teljes légtér -, és feladatintegráció.

\section{Alkalmazási és vezetési-irányítási szempontok}

Alapvetően a megfontolandó kérdések a pilóta nélküli légijármü rendszerek esetében is ugyanazok, vagy hasonlóak, mint a pilóta vezette légi jármüveknél, azonban vannak jelentős különbségek is az alkalmazhatóságuknál.

Az egyik ilyen eltérésnek tekinthető kérdés az erőforrások feletti vezetési-irányítási jogkör kérdése. Mivel a potenciális hadszíntereken, a közelmúlt légi hadviselési tapasztalatai alapján kijelenthetjük, egyre nagyobb igény merül fel az ISTAR-erőkbe integrált pilóta nélküli légijármü rendszerek alkalmazására. A jelenkor gyakorlata szerint a hadszíntéri stratégiaihadmüveleti szintü célokra is bevethető pilóta nélküli légijármü rendszerekkel kapcsolatos döntések (feladat-meghatározás, célpont-kiválasztás, stb.) az összhaderőnemi parancsnok kompetenciájában maradnak.

A komponens parancsnokságok (funkcionális egységek) parancsnokai addig tarthatják meg a vezetési-irányítási jogosultságaikat, amíg az összhaderőnemi parancsnok a hadműveleti, vagy harcászati vezetési-irányítási jogköröket delegálja számukra.

Az összhaderőnemi müveleteknél kritikus az erőforrások és feladatok allokációja is. A hadszíntereken is bevethető pilóta nélküli légijármű rendszerek iránt nagy az igény, alaposan meg kell gondolni, hogy milyen feladatra és hová osztják be azokat. A hadszíntereken jellemzően három eltérő célú alkalmazási mód fordul elő: felderítési-megfigyelési és célpontmeghatározó-; harcászati vezetési-irányítási-; és összhaderőnemi tủztámogatási müveletek.

A felderítési-megfigyelési és célpont-meghatározó bevetéseknél minél több célpontot akarnak felderíteni egy bevetés alatt, a harcászati vezetési-irányítási bevetéseknél például valós időben, hosszú ideig követnek egy célpontot (pl. egy jármüvet), az összhaderőnemi 
tủztámogatásnál pedig célkezelési adatokat gyüjtenek és akár lézeres tűzmegjelölést, vagy tényleges fegyverbevetést végeznek.

Tervezéskor és bevetéskor az elérni kívánt célt és hatást kell meghatározni, nem a konkrét légi jármüvet, mert a jól definiált céltól függően több légijármü is alkalmas lehet a feladatok végrehajtására. A pilóta nélküli légijármü rendszerek jövőbeli összhaderőnemi alkalmazásakor valószínüleg a hálózatos felépítés lesz a meghatározó. A hálózatos adatkapcsolatok több felhasználó számára is elérhetővé teszik a pilóta nélküli légijármü rendszerek hasznos terheit és telemetrikus adatait. A hálózati átjárókkal a sávszélesség is jobban elosztható lesz, egy irányító állomásról több eszközt irányíthatnak, a növekvő számítási és tárolókapacitás magasabb szintű előre programozott müködést tesz majd lehetővé, az egyre több és jobban hozzáférhető adatmennyiség feldolgozásához pedig új eszközök is kellenek majd.

Kategóriánként (1. sz. táblázat szerint) vizsgálva az alkalmazhatóságot a következőket állapíthatjuk meg: az 1. osztály méretéből adódóan általában hordozható, kézből indítható, egy kezelő által irányított eszköz, 50 km-nél kisebb hatósugárral, 2 óránál rövidebb ideig üzemel és gyorsan bevethető. A 2. osztály méretéből adódóan korlátozott hatótávú, jellemzően hadszíntéri bevetésü és előzetesen felderített területet igényel a fel- és leszálláshoz, szintén gyorsan bevethető. A 3. osztály jármüvei kifutópályát igényelnek, a bevetés több fázisra osztott. Ezek az eszközök a legösszetettebbek és a legjobb képességekkel rendelkeznek. A légtér tekintetében több mindent meg kell fontolni, mint az előző két osztály eszközei tervezésénél.

Hadmüveleti tervezésnél a pilóta által vezetett jármüvekre érvényes doktrínák módosításokkal a pilóta nélküli légijármü rendszerek esetében is alkalmazhatóak. Mérettől, küldetéstől, helyszíntől függetlenül minden pilóta nélküli repülést meg kell tervezni. A küldetés céljainak, feladatainak résztvevők általi teljes megértése biztosítja a sikert. A 2. és 3. osztályba tartozó járművek egyre többet repülnek a hadszínterek légterén kívül, ezért fontos a repülési útvonalak és engedélyek tisztázása, nemzetközi légtérben a nemzetközi törvények, szabályozások és szokások betartása. A hadszínterek légterében jellemzően az Légierő Komponens Parancsnokság (Joint Force Air Component Command - JFACC) a felelős a légtér menedzseléséért, ezért őket kell tájékoztatni az összes UAS-integrációs problémáról. Polgári légtérben a polgári légi irányítás a felelős. Ha ez nem létezik, vagy rosszul müködik, akkor a katonai légtérfelügyelet nyújthat támogatást a kereskedelmi légtérhasználóknak is.

A vészhelyzeti tervezés komplikált lehet, az információkat az adatkapcsolaton keresztül kapjuk meg. Nincs közvetlen tapasztalat, csak monitoron látjuk az adatokat, a kapcsolat meg is szakadhat. Minden pilóta nélküli jármü rendelkezik előre programozott kapcsolatvesztés esetére speciális üzemmóddal, melyeknek meg kell felelniük a légibiztonsági irányelveknek. Vészhelyzetekre terveznünk kell a jármü vészhelyzeti bázisra való átirányításával is.

A pilóta által vezetett rendszerek kihasználhatják a pilóta nélküli rendszerek képességeit és viszont. Már vannak próbálkozások annak megoldására, hogy a pilóta vezette járművek egy vagy több UAS-t irányíthassanak. Az együttmüködéssel megnövelhető a helyzetfelismerés képessége és a szenzorokkal lefedett területek mérete. Az ember vezette és az embernélküli jármüvek integrációja szárazföldi és tengeri jármüvek esetén is hasznos lehet.

Az interoperabilitás célja szabványosítani az adatátvitelt az irányító központok, a pilóta nélküli jármủvek vezetési-irányítási rendszereik között.

A pilóta nélküli légijármü rendszereknek képesnek kell lenniük a harci információk, felderítési és tüztámogatási adatok gyors átadására. Ez a képesség a felderítési ciklus lépésein alapszik. Az első lépés a felderítési célok és az információs igények kijelölése, megtervezése. Második lépés az adatgyüjtés. Harmadikként következik a begyüjtött adatok feldolgozása, elemzése, és végül a negyedik lépés a tájékoztatás, az információk megfelelő időben történő átadása a megfelelő szervezeteknek.

A légtérgazdálkodáshoz hasonlóan a távközlési frekvenciák kezelése is korlátozhatja az UAS-ok bevetését. Az előtervezéskor fel kell mérni a frekvenciákat, meg kell vizsgálni az 
adatbázisokat, hogy tervezni lehessen a használható frekvenciákat. Ismerni kell a zavaró interferenciákat, a rendelkezésre álló kapacitásokat, katonai és polgári müholdak elérhetőségét, tudatában kell lenni az ellenséges vagy éppen nem szándékos, baráti elektromágneses impulzusok érzékeny kommunikációs eszközeinkre gyakorolt hatásának.

További alkalmazási megfontolást igényel a bázisok optimális elhelyezése (pl. közelebb telepített bázisok rövidebb kijuttatási és visszatérési időt jelentenek), illetve maguknak az UASoknak a sebezhetősége az ellenséges UAS elhárító módszerek által (pl. célzott zavarás, irányítás átvétele).

\section{UAS-műveletek összhaderőnemi-, és koalíciós összefüggésben}

A pilóta nélküli légijármü rendszereket az egyes országok ugyan önállóan, maguk is beszerezhetik, mivel az nemzeti kompetencia, de ezeknek képeseknek kell lenniük integrálódni a közös NATO hadmüveletekbe. A teljes interoperabilitás csak szabványosítással érhető el.

Összhaderőnemi környezetben általában a következő küldetések hajthatóak végre: felderítési-megfigyelési és célpont-meghatározó müveletek jelentik még mindig az UAS-ok legfontosabb, legjellemzőbb, fö küldetés formáját, majdnem valós idejü képet adva a döntéshozóknak, lehetővé téve a bevetések azonnali kiértékelését, valamint a természeti katasztrófák elhárításában is segítséget nyújtanak. Csapásmérő küldetésekben a fegyvertelen pilóta nélküli jármüvek lézeres célmegjelölést végeznek harmadik fél számára, a felfegyverzettek pedig maguk mérnek csapást. Továbbá a jármüvek müködhetnek kommunikációs reléként (jeltovábbítás), hasznos terhüket felhasználhatják elektronikus hadviselésre, részt vehetnek kereső és mentőakciókban, tömegpusztító fegyverek detektálásában, logisztikai támogatást nyújthatnak nehezen megközelíthető terepeken, megfelelö szenzorokkal pedig rögtönzött robbanóeszközöket is felderíthetnek szárazföldön és tengeren egyaránt.

A tengerészeti müveletek különböznek a szárazföldi bevetésektöl és olyan kihívásokat támasztanak, mint a hullámzás, a sós víz okozta korrózió, a kevés kiindulási bázis, a tengeri platformok helyszüke, tehát a légijármüveket ennek megfelelően kell felkészíteni. Képesnek kell lenniük a gyors felemelkedésre és süllyedésre a kedvezőtlen időjárási viszonyok elkerüléséhez, módosított indító berendezések és szenzorrendszerek kellenek. Jellemző küldetések: vízalatti hadviselés tengeralattjárók és aknák ellen, vízfelszíni hadviselés vízi jármüvek és kalózok ellen, csapásmérés vízi jármüvekről szárazföldi célpontokra.

A szárazföldi műveletek nagyrészt megfelelnek az összehaderőnemi müveleteknél bemutatottakkal, de a városi bevetések egyedi kihívásokat jelentenek: rádiós összeköttetést kell biztosítani a szárazföldi csapatokkal, be kell tartani a hadviselés szabályait a civil lakosok közelségére figyelemmel is (pl. nem lehet rakétát lőni a forgalmas út mellett parkoló célpontra, ha a járókelők is bekerülhetnek a robbanás hatósugarába a járulékos veszteségek minimalizálása érdekében). Mozgó jármüveket kell követni nem ellenőrzött területeken, vagy kitérő manővereket kell végrehajtani, gyorsan kialakuló eseményeket kell kiértékelni, a légijármünek halkan kell közlekednie, különösen éjszaka, és ügyelni kell a más haderőnemek, ügynökségek által egyidejüleg müködtetett hasonló pilóta nélküli eszközökre is.

\section{DOKTRINÁLIS SZEMPONTOK}

A NATO koalíciós erőinek sikeres bevetéséhez létfontosságú hatékony és pontos doktrínával felvértezni a harcoló katonákat. Ezek jelentik a vezérfonalat a csapatok alkalmazásában, amelyeket megfelelő kiadványrendszerben terjesztenek. A doktrína szabványosítja a terminológiát, a kapcsolatokat, a felelösségeket és a folyamatokat a koalíciós erök között, hogy a parancsnokok és törzseik a stratégiai, hadmüveleti és harcászati problémák megoldására koncentrálhassanak. 


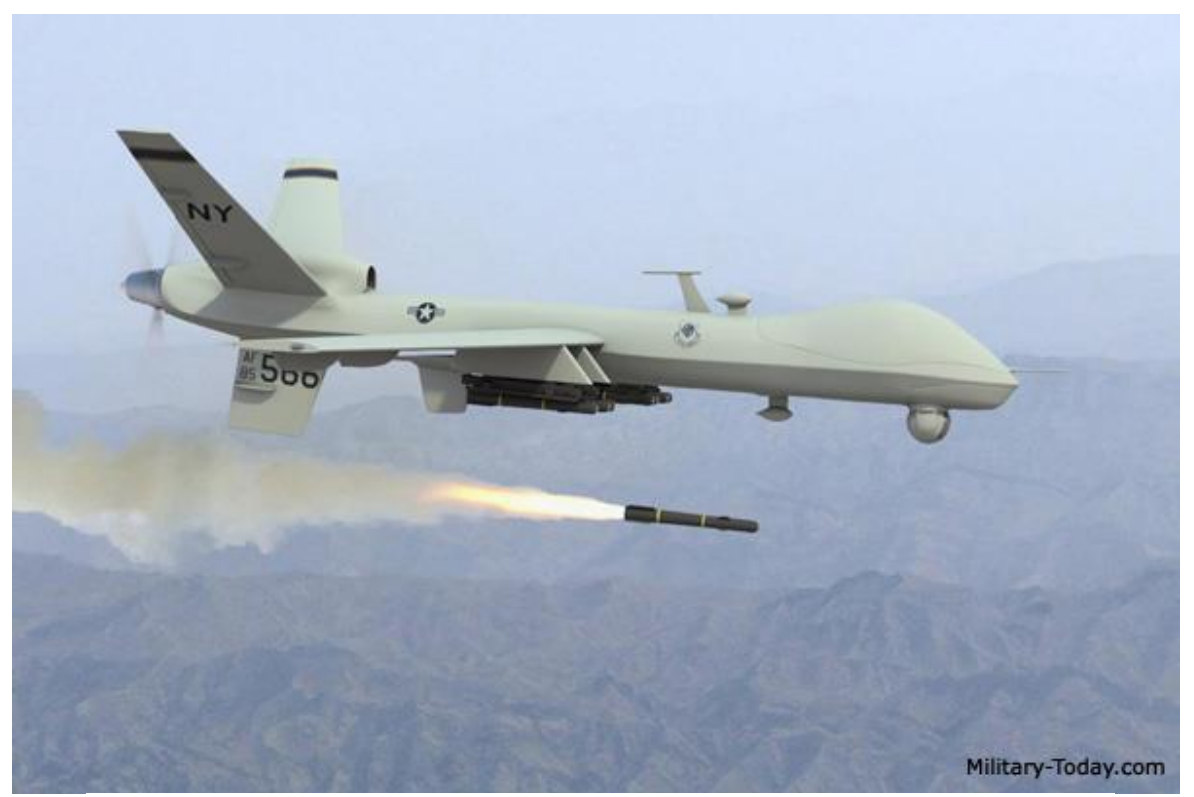

2. kép: MQ-9 Reaper pilótanélküli légijármü

(forrás: http://www.military-today.com/aircraft/mq9_reaper.htm/)

\section{Az alapvető légierő szerepkörök és légi müveletek ${ }^{3}$}

A hatályos releváns NATO légi hadviselési doktrína alapvetően szerepkörként értelmezi a tradicionális légi műveleteket, úgy mind légi szembenállás, támadó (csapásmérési) tevékenységek, légi mozgékonyság, felderítési-megfigyelési müveletekkel való hozzájárulás az összhaderőnemi erőfeszítésekhez.

Általános megközelítés szerint a pilóta nélküli légijármü rendszerek, ugyanolyan platformnak, tekinthetőek, mint a pilóta által vezetett fegyverrendszerek a müveleti alkalmazási formákat illetően. A UAS-ok gyakorlatilag, mint az adott szerepkörre létrehozott komplex légi támadó kötelékek (Composite Air Operations - COMAO) részeként a képességeiknek megfelelő feladattal integrálódnak.

\section{Légi szembenállás}

A légi szembenállási szerepkör (müveletek) (Counter Air Operations - COA) elsődleges célja, a légierő tradicionálisan értelmezett feladata, hogy a légtérellenőrzés megfelelő fokozatát, rendszerint a légi fölényt biztosítsa (megtartsa, kivívja) a meghatározott hadszíntéren, vagy annak megfelelő szegmensében és időintervallumában.

Ezzel a légierő biztosíthatja, hogy a NATO csapatok úgy tudjanak tevékenykedni, hogy az ellenséges légierö jelentősen ne tudja akadályozni a meghatározott célok elérését.

Definíciószerüen: „a légi szembenállás, mint gyüjtőfogalom magába foglalja azokat a rendszabályokat, eljárásokat és eszközöket, melyek végrehajtása illetve hatása az ellenség merev- és forgószárnyú repülőeszközei, valamint pilóta nélküli légijármüvei által végrehajtott felderitö, támadó és védelmi tevékenysége hatékonyságának csökkentésére illetve megszüntetésére irányulnak. " [6, 41. oldal]

\footnotetext{
${ }^{3}$ AJP 3.3 B Allied Joint Doctrine for Air and Space Operations. p.I - 8 - I -16.
} 
A légi szembenállási müveletek eszközrendszere elsősorban a vadász- és vadászbombázó harcászati repülőgépek, a légvédelmi rakéta- és tüzér-fegyverrendszerek, valamint az elektronikai hadviselési bevetéseit integrálják. E szerepkörrel kedvező feltételek teremthetők a baráti erők számára a további hadműveletek sikeres végrehajtásához.

A légi szembenállás további két alkategóriára osztható: támadó- és védelmi légi szembenállásra. (Offensive -, and Defensive Counter Air Operations - OCA, DCA)

Az offenzív-, és defenzív légi szembenállási aktivitások rendszerint azonos erőkkel, azonos légtérben történnek, így differenciálásuk rendszerint praktikusan nem elképzelhető.

A pilóta nélküli légijármü rendszerek széleskörüen alkalmazhatóak a védelmi-, és támadó légi szembenállás eszközeként, felderítö-, elektronikai hadviselési-, csapásmérési-, és figyelemelterelési-megtévesztő feladatkörökben egyaránt.

\section{A (légi) támadó szerepkör}

A (légi) támadó szerepkör a légierő lényegi, centrális eleme, amely képességgel meghatározó változásokat képes kiharcolni a hadszíntéren az ellenség releváns elemének pusztításával, illetve rombolásával. A légi csapások eredményei harcászati, hadmüveleti és hadászati jelentőségüek is lehetnek, a támadott célok jelentőségétnek függvényében. A (légi) támadó szerepkör további alkategóriái: a stratégiai légi támadások, a felszíni (földi, tengeri) erők elleni müveletek és információs tevékenységek.

A stratégiai jelentőségü célpontok elleni légi csapásokra, légi támadásokra való igény már a katonai repülés hajnalán jelentkezett, közvetlenül a légi felderítési feladatok sikereinek és jelentőségének a felismerése után. A stratégiai légi támadás alapvető célja, hogy a szembenálló fél stratégiai súlypontjait gyengítve, a háború megkezdéséhez, vagy folytatásához szükséges képességeket gyengítse, ezáltal a saját erők stratégiai céljainak a megvalósítását támogassa. Így az ellenség elveszti az akciószabadságát, a hadászati kezdeményezés fontos képességét, ami a katonai vereség előjelét hordozza magában.

Az ún. „célkezelési-paradigmának” (targeting-metódus) megfelelően a légi támadások célkeresztjében a leggyakrabban szembenálló fél politikai rezsim vezetése, hadereje és lakossága, stratégiai erőforrásai és csapásmérő erői, valamint vezetési-irányítási struktúrái állhatnak.

A felszíni erők elleni müveletek (Counter-Surface Force Operations - CFO) közül, hazánk geostratégiai diszlokációját tekintve, a potenciálisan számításba vehető müveleti alkalmazási formákat fejtem csak ki. Kiindulási feltételként kijelenthetjük, hogy a légi szembenállási szerepkörben megvalósított légtérellenőrzési fokozat (légi fölény/légi uralom) eredményessége alapvetően meghatározza a felszíni erők elleni műveletek sikerét, vagy sikertelenségét. Más megfogalmazásban a légierő a légi szembenállási müveletekkel megteremti a feltételeit a szárazföldi-haditengerészeti erők müveleteihez, biztosítja a csapatok manőverszabadságát ezzel teremtve meg a sikeres müveletek légi feltételét.

A felszíni erők elleni mủveletek közül számunkra a tengeri-légi müveletek nem relevánsak. Azonban a légi lefogás (Air Interdiction - AI) és a közvetlen légi támogatás (Close Air Support - CAS) a nemzeti légierőnk számára is alapvető feladatrendszerként jelentkezik.

A légi lefogási mủveletek az ellenség harci potenciálja kihasználásának korlátozása, vagy késleltetése érdekében végrehajtott összhaderőnemi müveletek elemeként értelmezhetőek.

A légi lefogási müveletek alapvetően a szárazföldi erők tűzeszközeinek hatótávolságán kívüli célpontok elleni légi csapások halmazaként fogható fel. A müveletek alapvető célja az szembenálló fél tartalékai előrevonásának, szétbontakozásának, a számára előnyos harcrend kialakításának a megakadályozása, valamint az ellenség manőver- és utánpótlási lehetőségeinek korlátozása. Miután a müveletek a saját csapatok első lépcsőjétől távolabbi térrészben valósul meg, így a légierő erőforrásainak és a szárazföldi erők tüzének és manővereinek részletes koordinációjára nincs szükség. 
A potenciális légi müveleteket az 2. sz. táblázatban összegeztem:

\begin{tabular}{|c|c|c|c|}
\hline Légi szembenállás & (Légi) Támadás & Légi mozgékonyság & $\begin{array}{c}\text { Felderítési- } \\
\text { megfigyelési } \\
\text { műveletekkel való } \\
\text { hozzájárulás az } \\
\text { összhaderőnemi } \\
\text { erőfeszítésekhez }\end{array}$ \\
\hline $\begin{array}{l}\text { Támadó légi } \\
\text { szembenállás: } \\
\text { - } \quad \text { légvédelem } \\
\text { elnyomása; } \\
\text { - } \text { kísérés; } \\
\text { - } \text { repülőterek } \\
\text { támadása; } \\
\text { - légtér megtisztítás }\end{array}$ & Stratégiai légi támadás & $\begin{array}{l}\text { Légi szállítás: } \\
\text { — } \quad \text { stratégiai légi szállítás; } \\
\text { - } \text { harcászati légi szállítás: } \\
\text { légi logisztikai szállítás, } \\
\text { légi mozgékonyságú } \\
\text { müveletek, légi } \\
\text { egészégügyi kiürítés, } \\
\text { nem harci légi } \\
\text { evakuálás, }\end{array}$ & $\begin{aligned} & \text { ISR-müveletek: } \\
\text { - } & \text { felderítés; } \\
\text { - } & \text { megfigyelés; } \\
\text { - } & \text { hírszerzés. }\end{aligned}$ \\
\hline $\begin{array}{l}\text { Védelmi légi } \\
\text { szembenállás: } \\
\text { - } \quad \text { aktív légvédelem; } \\
\text { - } \quad \text { passzív légvédelem. }\end{array}$ & $\begin{array}{l}\text { Felszíni erők elleni } \\
\text { műveletek: } \\
\text { - a légierő } \\
\text { hozzáiárulása a } \\
\text { szárazföldi erők } \\
\text { műveleteihez: } \\
\text { - légi lefogás; } \\
\text { - közvetlen légi } \\
\text { támogatás; } \\
\text { - a légierő } \\
\text { hozzájárulása a } \\
\text { haditengerészeti erők } \\
\text { műveleteihez. }\end{array}$ & $\begin{array}{l}\text { Légi utántöltés: } \\
\text { _ } \quad \text { légi hidak támogatása; } \\
\text { - } \text { légijárművek } \\
\text { áttelepülésének } \\
\text { támogatása } \\
\text { - } \quad \text { készültségi } \\
\text { repülőgépek (Air } \\
\text { Policing) támogatása } \\
\text { - } \text { globális csapásmérés } \\
\text { támogatása; } \\
\text { - } \quad \text { különleges műveletek } \\
\text { támogatása } \\
\text { - légi hadjárat (folyó } \\
\text { műveletek) } \\
\text { támogatása. }\end{array}$ & Űrtámogatás \\
\hline
\end{tabular}

2. sz. táblázat: A légi múveletek összegzése (forrás: saját szerkesztés)

A közvetlen légi támogatás szoros és folyamatos koordinációt igényel, mivel a CASbevetések a saját szárazföldi csapatok közvetlen közelében, tüzérségi fegyverrendszereinek hatótávolságán belül kerülnek végrehajtásra. A közvetlen légi támogatás alapvető célja a közvetlen harcérintkezésben lévő csapataink manővereinek tüzzel való támogatása, a közvetlen közelségben elhelyezkedő felszíni célok pusztítása, manővereinek korlátozása.

A müveletek végrehajtó elemeiként elsősorban a pilóták által vezetett légijármüvek (harcászati repülőgépek, forgószárnyas rendszerek) a jellemzőek, de a feladatok komplex jellegéből fakadóan egyre több feladatot lehet allokálni a pilótanélküli légijármü rendszerekre, akár a tüzcsapás kiváltása, vagy ahhoz való információs támogatás végrehajtása is eredményesen végrehajtható ezen eszközökkel.

A közvetlen légi támogatás jellegéből fakadóan a baráti tüz általi fenyegetés magasfokú, ami a pilótanélküli eszközök alkalmazásával jelentősen csökkenthető.

\section{Légi mozgékonyság, légi szállítás}

A légi szállítás megteremti a személyi állomány és az anyagi-technikai eszközök légi úton történő mozgatásának lehetőségét az adott hadszíntéren belül és a hadszínterek (továbbá távoli hadszíntér és hátország) között egyaránt. 
A pilótanélküli légijármủvek légi szállításban való alkalmazásáról való gondolkozás még kezdeti stádiumban van jelenleg. Vannak projektek (pl. Unmanned Cargo Aircraft - UCA), amelyek erre irányulnak, de még doktrinális szinten, a mindennapi gyakorlat szintjén nem relevánsak.

\section{Légi utántöltés}

A légi utántöltés területén folynak kísérletek és fejlesztések az UAV-rendszerek légi utántölthetőségére, valamint hogy pilótanélküli légijármüveket lássanak el légi utántöltő (tanker) képességekkel (pl. MQ-25 Boing-fejlesztés).

Ezen képességek, azonban, hasonlóan a légi szállítás részben megfogalmazottakhoz, doktrinális szinten, a mindennapi gyakorlat szintjén nem relevánsak.

\section{Felderítési-megfigyelési műveletekkel való hozzájárulás az összhaderőnemi erőfeszítésekhez}

A felderítési-megfigyelési mủveletek kiemelt célja a hatékony vezetői döntések meghozatalához és a kurrens müveletek végrehajtásához szükséges (közel) valós idejü információk biztosítása, az ellenség tevékenységeiről, erőforrásairól, és a harcmezőről a saját csapatok részére.

A felderítési-megfigyelési müveletek jelentős szegmensét már pilótanélküli légijármü rendszerekkel tudjuk csak Szövetséges szinten elképzelni. Ez a müveleti képesség volt az első az UAV-k katonai szerepében és manapság is ez a legjelentősebb része a feladatportfóliójuknak. A pilótanálküli rendszerek által végrehajtott ISR-müveletek, az információk felhasználásának céljától illetve szintjétől függően - stratégiai, hadmüveleti és harcászati szintü lehet.

\section{KÖVETKEZTETÉSEK}

A pilóta nélküli légijármü-rendszerek egyre nagyobb jelentőségủek a Szövetséges (koalíciós) és (nemzeti) összhaderőnemi szinten egyaránt. A NATO kiemelt figyelmet fordít a UAVrendszerek alkalmazása doktrinális feltételeinek a biztosítására, a megszerzett müveleti tapasztalatok megosztására. A sajátos müveleti szabványosítási eszközrendszerével növelni kívánja a pilótanélküli légijármü rendszerek alkalmazásának a hatékonyságát a potenciális müveletekben.

Ebben a folyamatban jelentős szerepet játszik a NATO Összhaderőnemi Légierő Tudásközpont (Joint Air Power Competence Centre, Kalkar, Németország) is, amelynek egyik fő kutatási területe a pilótanélküli légijármü rendszerek alkalmazásának komplex kérdésköre. Folyamatosan kutatja a témát, publikálja a kutatási eredményeket és integrálja azokat a Szövetség doktrinális rendszerébe. A 2010-ben kiadott pilóta nélküli légijármü-rendszerek alkalmazásának stratégiai koncepciója részletesen elemzi a mai és a jövőbeli pilóta nélküli légijármü rendszerek képességeinek alkalmazásának feltételrendszerét és koncepcióját kifejezetten az összhaderőnemi müveleti forgatókönyvek esetére. A pilóta nélküli légijármü rendszerek alkalmazási elveinek jövőbeli következményei több területet is érintenek, bevetésüket a katonai müveletek teljes keresztmetszetébe integrálni szükséges, be kell öket illeszteni a NATO oktatási, kiképzési, gyakorlati és kiértékelési rendszereibe egyaránt. Ezek az elvek segítik a technológiai fejlesztéseket, a beszerzésekhez szükséges hadmüveleti követelmények kialakítását és támogatják a parancsnokokat a pilóta nélküli légijármü rendszerek képességeinek integrált és hatékony kihasználásában.

Szükséges lenne még a pilóta nélküli légijármü rendszerek bevetéseinek szabványosított szabályozása, ami ma még hiányzik a NATO-ban. A STANAG 4670 a pilóta nélküli légijármü rendszerek kezelőinek a képzési a minimumát határozza meg. Szintén korlátokat jelentenek az 
adatkapcsolatok. Ezek megszakadása akár az eszköz elvesztéséhez is vezethetnek. Sebezhetőségüket titkosítással, szükösségüket redundáns csomópontokkal és az elérhető müholdas sávszélesség növelésével lehetne orvosolni.

Az egyre növekvő alkalmazási igény miatt egyre fontosabb a bevetési és rendszerintegrációs kihívások kezelése. A pilóta nélküli és a pilóták vezette eszközök alkalmazását zökkenőmentesen kell összehangolni a haderőnemek között, a pilóta nélküli légijármürendszerekkel beszerezhető jelenlegi és jövőbeli C4ISR-adatokat (vezetés, irányítás, kommunikáció és számítástechnika, hírszerzés, megfigyelés és felderítés) be kell illeszteni az információfeldolgozási ciklusba. Figyelembe kell venni, hogy ugyan a vezetési-irányítási folyamatok a pilóta nélküli légijármủ rendszerek esetében nagyon hasonlóak a pilótával vezetett jármüvekéhez, de vannak komoly kihívások is emiatt. Például a fizikai távolság miatti robusztus adatkapcsolat igény merül fel, vagy a folyamatos (kézi) és az elöre programozott irányítás kettőssége, illetve a pilóta nélküli légijármű rendszerek irányítását repülés közben átadhatják más kezelőknek is.

Megítélésem szerint a pilóta nélküli légijármü rendszerek, ugyanolyan platformnak, tekinthetőek, mint a pilóta által vezetett fegyverrendszerek a müveleti alkalmazási formákat illetően, az UAS-ok gyakorlatilag, mint az adott szerepkörre létrehozott komplex légi támadó kötelékek (Composit Air Operations - COMAO) alkotó elemeiként a képességeiknek megfelelő feladattal integrálódhatnak.

A pilóta nélküli légijármü rendszerek széleskörüen alkalmazhatóak a védelmi-, és támadó légi szembenállás eszközeként, felderítö-, elektronikai hadviselési-, csapásmérési-, és figyelemelterelési-megtévesztő feladatkörökben egyaránt. A szárazföldi csapatok tüzzel való támogatási feladatainak komplex jellegéböl fakadóan egyre több feladatot lehet allokálni a pilótanélküli légijármü rendszerekre, akár a tűzcsapás kiváltása, vagy ahhoz való információs támogatás végrehajtása is eredményesen végrehajtható ezen eszközökkel.

A légi utántöltés és légi szállítás területén folynak kísérletek és fejlesztések az UAVrendszerekkel való feladat-végrehajtásra. A légi utántölthetőségére, valamint hogy pilótanélküli légijármüveket lássanak el légi utántöltő- (tanker) valamint légi szállítási képességekkel (pl. MQ-25 Boeing-fejlesztés, Unmanned Cargo Aircraft - UCA projekt)

Ezen képességek, azonban doktrinális szinten, a mindennapi gyakorlat szintjén még nem relevánsak. A felderítési-megfigyelési müveletek jelentős szegmensét már pilótanélküli légijármü rendszerekkel tudjuk csak Szövetséges szinten elképzelni. Ez a müveleti képesség volt az első az UAV-k katonai szerepében és manapság is ez a legjelentősebb része a feladatportfóliójuknak. A pilótanélküli rendszerek által végrehajtott ISR-müveletek, az információk felhasználásának céljától illetve szintjétől függően - stratégiai, hadmüveleti és harcászati szintü lehet. 


\section{FELHASZNÁLT IRODALOM}

[1] SZABOLCSI R.: Légi robotok automatikus repülésszabályozása, Óbudai Egyetem Bánki Donát Gépész És Biztonságtechnikai Mérnöki Kar, Budapest, 2016, ISBN 978-6 155460-23-4;

[2] JDN 3/10 - Unmanned Aircraft Systems: Terminology, Definitions and Classification, The Development, Concepts and Doctrine Centre Ministry of Defence, 2010, https://assets.publishing.service.gov.uk/government/uploads/system/uploads/attachment _data/file/432646/20150427-DCDC_JDN_3_10_Archived.pdf（letöltve: 2018. augusztus 17.)

[3] PALIK M.: A pilóta nélküli légijárművek katonai alkalmazása, In: Békési Bertold, Bottyán Zsolt, Dunai Pál, Halászné dr Tóth Alexandra, Makkay Imre, Palik Mátyás, Restás Ágoston, Wührl Tibor, Palik Mátyás (szerk.) Pilóta nélküli repülés profiknak és amatőröknek. 320 p. Budapest: Nemzeti Közszolgálati Egyetem, 2013. pp. 281-297. (ISBN:9789630869232)

[4] SZABÓ M.: A pilóta nélküli repülő eszközök katonai alkalmazásának lehetőségei és sajátosságai, Repüléstudományi Közlemények 2018/2. pp. 1-16. http://www.repulestudomany.hu/kulonszamok/2013_cikkek/2013-2-61-

Szabo_Miklos.pdf (letöltve: 2018. augusztus 20.)

[5] Strategic Concept of Employment for Unmanned Aircraft Systems in NATO; January 2010, NATO, Joint Air Power Competence Centre, von-Seydlitz Kaserne, Kalkar, Germany, https://www.japcc.org/portfolio/strategic-concept-of-employment-forunmanned-aircraft-systems-in-nato/, (letöltve: 2018. augusztus 20.)

[6] Magyar Honvédség Légierő Doktrínája (MH DSZOFT kód: 13013) Nyt. szám: 563/614/2004./LEP

[7] KRAJNC Z., CSENGERI J.: A légierő képességei a hibrid fenyegetésekkel szemben, Hadtudományi Szemle 2017/4 pp. 112-125.

[8] KOMJÁTHY 1. J.:, CSENGERI J. A távirányított és pilóta nélküli repülőrendszerek alkalmazási lehetőségei a felkelök elleni müveletek során, Honvédségi Szemle, (2017/6.) Pp. 81-92. (2017)

[9] KOMJÁTHY L. J.: A müveleti környezet és körülményei változásainak hatása napjaink katonai tevékenységére, Hadtudományi Szemle X.:(3) pp. 63-77. (2017)

[10] KRAJNC Z. CSENGERI J.: Hybrid warfare from military air perspective In:8. medzinárodná vedecká konferencia: "National And International Security 2017". 614 p. Liptovsky Mikulas: Akadémia ozbrojených síl generála Milana Rastislava Štefánika, 2017. pp. 254-262. (ISBN:978-80-8040-551-9)

[11] KRAJNC Z.; CSENGERI J.: Early concepts and theories of employment of air power In: 12. medzinárodná vedecko-odborná konferencia: Management - Theory, Education and Practise 2016. 346 p. Liptovsky Mikulas: Akadémia ozbrojených síl generála Milana Rastislava Štefánika, 2016. pp. 164-171. (ISBN:978-80-8040-536-6)

[12] CSENGERI J.: „Operation Allied Force” A NATO légi háborúja a dél-szláv válság megoldása érdekében 1., Repüléstudományi Közlemények, XXV:(1) pp. 114-125. (2013)

[13] J. CSENGERI Material management and transportation procedures in air force logistic operations, In: Manažment - teória, výučba a prax 2014: zborník príspevkov z medzinárodnej vedecko-odbornej konferencie. 380 p. 2014. pp. 222-233. (ISBN:978-808040-496-3) 
[14] NÉMETH A.: UAV-k alkalmazása a közfeladatok ellátása során I., Hadmérnök, XIII. évfolyam 2 szám - 2018. június

[15] P. TUCKER In Ukraine, Tomorrow's Drone War Is Alive Today, https://www.defenseone.com/technology/2015/03/ukraine-tomorrows-drone-war-alivetoday/107085/ (letöltve: 2018. augusztus 13.)

[16] KOVÁCS L., VÁNYA L.: Pilóta nélküli repülőgépek a terrorizmus elleni harcban, Repüléstudományi Közlemények (1997-TÖL) 19: (Különszám) pp. 1-16.

[17] PALIK M.: Need for Unmanned Aircraft System, Hadmérnök II:(2) pp. 145-148. (2007), http://hadmernok.hu/archivum/2007/2/2007_2_palik.html (letöltve: 2018. augusztus 14.) 